\title{
The impact of climate risks on Russia's economic development: example of the North Caucasian Federal District
}

\author{
Artem S. Lukyanets $\mathbb{B}^{\otimes}$, Alexey S. Bragin \\ Institute for Demographic Research FCTAS RAS, \\ 6 Fotievoy St, bldg 1, Moscow, 119333, Russian Federation \\ $\square$ artem_ispr@mail.ru
}

\begin{abstract}
This article presents an analysis of climate risks' structure and effects on the Russian Federation's economic development. Despite the existed theoretical background, it is not clear about the leading risk factor, human adaptation to it, and the subsequent effect on the economy. This happens since some climate risks can be controlled; therefore, their impact on the regional economy is minimal. Thus, we are interested in the scope of certain climate risks affecting the Russian Federation's economic situation. We have selected the North Caucasian Federal District because it is strongly susceptible to the most severe climate risks as droughts and floods. Considering the complexity of the climate risk formation process, we use mixed-methods. It allows identifying the quantitative component and analyzing the object in the framework of the existing theoretical background. During our research, we determined the cause of climate risk formation in the Russian Federation. With the collected empirical data for 2010-2013 regarding the level of drought, precipitation, and crop productivity, we have compared the region's economic situation with climate risks. It was determined that despite the clear manifestation of climate risks in the North Caucasian Federal District, the economic damage to the region is minimal due to the high level of the region's resistance to the existing threats and their localization. Nevertheless, guided by the theoretical and methodological basis of the topic under study and revised data on the migration loss of the region, we can assume that the North Caucasian FD's climate risks are expressed in the concept of climate migration, and this process has an increasing dynamic.
\end{abstract}

Keywords: North Caucasus, climate change, economic development, climate risks, climate migration

Acknowledgements: The article was prepared with the financial support of RFBR, project No. 20-010-01006.

Conflicts of interest: The authors declare no conflict of interest.

Article history: received - 5 January 2021; revised - 7 February 2021; accepted 13 March 2021.

For citation: Lukyanets, A.S., \& Bragin, A.S. (2021). The impact of climate risks on Russia's economic development: Example of the North Caucasian Federal District RUDN Journal of Economics, 29(2), 439-450. http://dx.doi.org/10.22363/2313-2329-2021-29-2-439-450

(C) Lukyanets A.S., Bragin A.S., 2021

(i) This work is licensed under a Creative Commons Attribution 4.0 International License https://creativecommons.org/licenses/by/4.0/ 


\title{
Влияние климатических рисков на экономическое развитие России: пример Северо-Кавказского федерального округа
}

\author{
А.С. Лукьянец® ${ }^{\square}$, А.Д. Брагин \\ Институт демографических исследований ФНИСЦ РАН, \\ Российская Федераиия, 119333, Москва, ул. Фотиевой, д. 6, корп. 1 \\ artem_ispr@mail.ru
}

\begin{abstract}
Аннотация. Представлен анализ структуры и последствий климатических рисков в контексте экономического развития Российской Федерации. Несмотря на существовавшую теоретическую базу, остаются не выявлены основные факторы риска, адаптация к ним человека и последующий эффект для экономики. Это происходит из-за того, что некоторые климатические риски можно контролировать, поэтому их влияние на региональную экономику минимально. Цель исследования - определить, в каком объеме те или иные климатические риски влияют на экономическое развитие в Российской Федерации. Для изучения выбран Северо-Кавказский федеральный округ, потому что, согласно многочисленным отчетам Росгидромета, этот регион сильно подвержен самым серьезным климатическим рискам, выраженным в виде засух и наводнений. Учитывая сложность процесса формирования климатических рисков, использовался смешанный метод исследования, позволяющий не только выявить количественную составляющую, но и проанализировать объект в рамках существующей теоретической базы. В ходе исследования определена причина формирования климатических рисков в Российской Федерации. На основе собранных эмпирических данных за 2010-2013 годы относительно уровня засухи, осадков и урожайности сельскохозяйственных культур сравнивалась экономическая ситуация в регионе с воздействием климатических рисков. Установлено, что, несмотря на явное проявление климатических рисков в Северо-Кавказском федеральном округе, экономический ущерб региона минимален, ввиду высокого уровня устойчивости региона к существующим рискам и их локализации. Тем не менее, руководствуясь теоретикометодологической базой исследуемой темы и полученными данными о миграционной убыли региона, можно предположить, что климатические риски Северо-Кавказского ФО выражаются в концепции климатической миграции и этот процесс имеет увеличивающуюся динамику.
\end{abstract}

Ключевые слова: Северный Кавказ, изменение климата, экономическое развитие, климатические риски, климатическая миграция

Благодарности: Исследование выполнено при финансовой поддержке РФФИ в рамках научного проекта № 20-010-01006.

Conflicts of interest: The authors declare no conflict of interest.

История статьи: поступила в редакцию - 5 января 2021 г.; проверена - 7 февраля 2021 г.; принята к публикации - 13 марта 2021 г.

Для цитирования: Lukyanets A.S., Bragin A.S. The impact of climate risks on Russia's economic development: example of the North Caucasian Federal District // Вестник Российского университета дружбы народов. Серия: Экономика. 2021. Т. 29. № 2. С. 439-450. http://dx.doi.org/10.22363/2313-2329-2021-29-2-439-450

\section{Introduction}

Today a lot of attention is paid to human interaction with the environment. This happens because the main threat to humanity became the direct result of human activity at the turn of the 20-21 century. The unsustainable use of natural re- 
sources and environmental pollution from cars, factories, and mining enterprises have significantly affected climate change across the planet. Today, the average global temperature is about $1{ }^{\circ} \mathrm{C}$ higher than the pre-industrial level, and according to scientists, this indicator can increase to a catastrophic $2-3{ }^{\circ} \mathrm{C}$ (Harmeling et al., 2015). Thus, the losses and damage caused by climate change are now a part of reality, and we should cope with it.

In this context, the study of climate change's effects is an extremely relevant issue to minimize its negative consequences. One of the derivatives of climate change is climate risks that affect people's everyday lives and pose a severe threat to private property and the economy. The concept of climate risk and trouble in general implies: a) the presence of an extreme natural phenomenon, both predicted and unexpected; b) human activity subjected to damage due to the specified event (Hewitt, 1997). Therefore, climate risks have a reasonably broad basis for occurrence.

Speaking about climate risks in the Russian Federation, it should be noted that according to one of the most well-known international organizations investigating climate change effects - GERMAN WATCH, Russia pays little attention to environmental management and pollution, taking 52 places out of 61 in the 2020 rating. ${ }^{1}$ Moreover, according to the IDMC (Internal displacement monitoring center), the rate of climate migration in Russia is significantly increasing as the number of people who were forced to change their place of residence due to natural disasters reached a peak in 2019 over the past five years with an amount of 12,000 people. ${ }^{2}$ These factors indicate that Russia is inclined to face climate risks caused by human activity (environmental impact) and the natural component (climatic phenomena caused by nature).

In a detailed study of Russia's regions regarding climate risks form and structure, North Caucasian Federal District stands out. According to the report of Roshydromet (The Federal Service for Hydrometeorology and Environmental Monitoring), in the North Caucasus exist frequent cases of rain floods and droughts (Report on climate risks.., 2017). This situation is unique for one region, not only because of the opposite of these phenomena but also because floods and droughts, and tropical cyclones are the most destructive climate risks in the world (Rusin, 2003). In other words, North Caucasus is under the influence of two serious climate risks at once. In this regard, we are interested in how these climate risks affect the North Caucasian Federal District's socio-economic situation.

It should be noted that despite the appearance of visible effects, the scientific community has not yet entirely determined whether climate risks have a direct impact on the economic situation of a particular region. ${ }^{3}$ In this regard, our study should reveal a relationship between climate risks and the region's economy on the example of the North Caucasian Federal District. It is evident that

${ }^{1}$ Climate change performance index. Russian Federation, 2020. Retrieved November 21, 2020, from https://www.climate-change-performance-index.org/country/russian-federation

${ }^{2}$ Internal displacement monitoring center. Russia, 2020. Retrieved November 18, 2020 , from https://www.internal-displacement.org/countries/Russia

${ }^{3}$ IPCC. (2007). Climate change 2007. The physical science basis. Working group I report. United Nations Environment Programme, 2007. Retrieved December 20, 2020, from http://www.ipcc.ch/ ipccreports/assessments-reports.htm 
with further climate change, climate risks will appear with greater regularity and intensity. Therefore, the study of their effects in the North Caucasus will help develop a detailed plan to minimize future risks.

\section{Structure of climate risks}

Climate risks carry severe socio-economic losses. With the destruction of property and the emergence of unforeseen costs to eliminate their consequences, climate risk is a threat to citizens' lives. Climate risks enchant a danger for the functioning of any society. Still, it is impossible to say unequivocally that extreme atmospheric events are a direct consequence of global warming and that they always cause damage to the economy. Moreover, according to R. McLeman (2013), a new term has recently occurred - climate migration, which is a consequence of climate risks. Its structure and damage to the economy can become more dangerous than any natural disaster.

Over the past few decades, the world has experienced extreme socioeconomic changes for which society was not ready. Climate change is already an aspect of uncertainty in the nearest term. Thus, changes in regional climatic features may lead to an increase in extreme atmospheric events. Consequently, the level of uncertainty will increase, which will require a rapid response.

To understand the structure of climate risks, we need to visualize the causal relationship between climate change and possible risks. This process is shown in Figure 1.

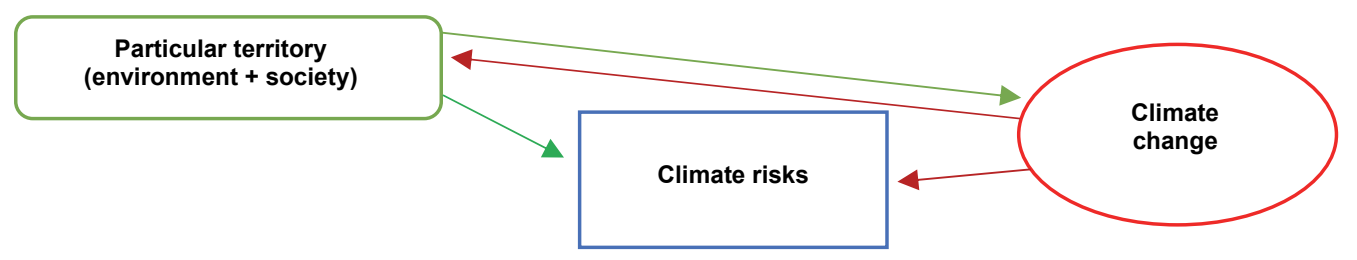

Figure 1. The process of climate risks occurrence

Source: Pelling, 2011.

As we can see, there are no natural risks directly related to human activities, i.e., climate change, but there is a poor adaptation of humans to nature. Climate risks are factors, both dependent variables (human activity) and independent (natural phenomena). Thus, climate risks do not always occur as a response to human activity, and therefore, they are tough to predict and control. This feature makes climate risks dangerous for modern society, which contains all processes and is unprepared for uncertainty. Negative consequences for the cash turnover of companies can occur even when the weather conditions were not extreme. Sometimes unusual, unseasonal, or merely unexpected weather events are enough to reduce income. The sectors most exposed to these risks are agro-food, construction, trade, energy, tourism, and transport (Report on climate risks.., 2017). Consequently, almost all critical sectors of the economy are at risk, and even minor natural phenomena can cause severe losses, which in turn can cause internal migration. As noted above, this type of migration is called "climate migration," i.e., climatic conditions with their subsequent impact on the economy are the reason for people's relocation. 
However, according to K. Hewitt (1997), the structure of climate risks implies adaptation to new realities. It is already possible to cope with some climate risks of a local seasonal nature (dams, etc.).

\section{Climate risks of North Caucasus}

The North Caucasus's climate risks are the most common in Russia, so the country's average situation perfectly characterizes the region's case. According to the report of Roshydromet, Russia is exposed to numerous climate risks, and the most serious is climate change. According to scientific estimation on Russian territory, climate warming is observed about 2.5 times stronger than the average in the world: for 1976-2016, the dynamics were $0.45^{\circ} \mathrm{C}$ for ten years (Report on climate risks.., 2017). In the context of the North Caucasian Federal District, an increase in the average annual temperature leads to a rise in climate risks such as droughts and an increase in precipitation. Despite the opposition of these phenomena, they may occur in the same region due to the seasonality and localization of manifestations. As a rule, one natural phenomenon will be replaced by another, increasing the load on the ecosystem and social infrastructure.

Changes related to the share of humidity in the Russian Federation's territory affect the annual total surface runoff's difference, especially in the North Caucasus. This process aggravates the average annual indicators associated with soils' aridity, so local droughts are formed. For example, in 2010, a large-scale lack occurred in the North Caucasian Federal District and the Southern Federal District, which caused a severe crop failure A.I. Strashnaya et al. (2011).

The second most crucial climate risk in the country and the North Caucasus is increased precipitation, which is a resultant factor for floods and landslides. Guided by I. Shkolnik et al. (2017), in Russia for 1976-2016, annual rainfall increased in dynamics $-2.1 \%$ for every ten years. In recent years, the North Caucasus rivers have experienced severe floods caused by abnormal precipitation, during which the indicators were several times higher than previous observations. According to experts, the frequency of rainfall in the summer season in the North Caucasus may increase by the middle of the 21 st century, which will affect the increase in the frequency and intensity of rain floods.

Thus, the North Caucasian Federal District is most exposed to two climate risks in the form of droughts and floods. We have determined that the reason for these climate risks was the change in the average annual temperature. However, it remains unclear how these risks affect the socio-economic situation in the region.

\section{Impact of risks on the economy}

As we noted, droughts and floods are among the most severe climate risks (Rusin, 2003). However, although these risks are not the most dangerous for human life, they can cause severe economic damage. Climate models as a comprehensive methodology for atmospheric modeling provide perspectives for studying the causes of drought and their application to forecasting. However, these models have severe drawbacks in modeling the regional climate. The intensity of the drought period can be quantified as the cumulative deviation of monthly precipitation from average and data on yields in the region (Balzter et al., 2007). The last method is not always suitable since some areas prone to drought are not initially 
eligible for agriculture (deserts, steppes). Therefore, the lack of data does not allow us to determine its level.

Agriculture is a sector of the economy that is highly dependent on climate change and thus is an excellent indicator to study the economic effects of climate risks. Among the most dangerous climate risks for agriculture are droughts, frosts, and excessive humidity. These climate risks directly affect crops' viability, significantly reducing their productivity and making it challenging to conduct fieldwork. All these factors cause low yields (Pavlova, Varcheva, 2016).

Another critical climate risk of the North Caucasian Federal District is heavy rains, which significantly impact the environment and human activity. Such heavy rainfall usually occurs in the fall, although it can occur at any time of the year, especially in winter (Report on climate risks.., 2017). Speaking about the consequences of heavy rains for the region's economy, it should be noted that unlike droughts, their effect is much more severe, since as a result of floods, a large part of the socioeconomic sphere is in danger. For example, heavy rainfall can affect yields, severely erode crops, and increase the water level in rivers, causing flooding and, thus, destroying social infrastructure. Also, floods in heavy rainfall cause the local population's temporary migration due to flooding of residential infrastructure.

Speaking about the impact of climate risks on regions' socio-economic situation, we should highlight climate migration. Climate migration is the movement of a person or groups of people, mainly due to sudden or gradual changes in the environment. In other words, climate migration is a phenomenon of climate change, as a result of which people are forced to leave their place of residence. This process can be temporary or permanent, as well as differentiated within one or more states. Many factors cause climate migration, but the main problem is that they cannot always be separated from political, social, and economic aspects (McLeman, 2013). Thus, it can be quite tricky to significantly determine the level of climate migration if the region's economic decline is not associated with climate risks.

Based on the theoretical and methodological basis, we have identified the most vulnerable sectors of the region's economy from droughts and floods. Further, it is necessary to analyze the existing empirical data on these sectors' functioning and the level of impact of climate risks. It is required to determine whether there is a relationship between them and, therefore, a correlation. Otherwise, we can argue that the North Caucasian Federal District has a sufficient level of vulnerability to the identified climate risks.

\section{The effect of drought}

When it comes to the analysis of the drought effects, it has a dual purpose: on the one hand, to determine its intensity and duration, and on the other, to delineate the extent of the affected area in the context of economic indicators. Statistical studies allow finding the probability of various degrees of drought in the presence of sufficiently long computational series and, thereby, minimize its consequences. However, the main problem of statistical methods is that they do not take into account significant climate change due to an increase in the average annual temperature, which in our case is a crucial risk factor (Mishra, Singh, 2010).

To determine the effects of drought in the North Caucasian Federal District, we take the yield indicator as a dependent variable since this region is actively used 
in agriculture. For example, in 2015, the area with the poor condition of winter grain crops at the time of termination of vegetation in the North Caucasian Federal District was $1 \%$ even though the autumn of 2015 was dry (Bereza et al., 2015). Therefore, data on crop yields are of decisive importance in forming economic indicators of the region because even in dry years, agriculture has a crucial role. As an independent variable, we take the fact of drought, because according to A.I. Strashnaya and T.A. Maksimenkova (2011), the observation for the period from 1891 to 2015 the number of extensive droughts lasting more than two months was 24 cases with a recurrence rate of $19 \%$ (on average, one severe drought for every five years). These indicators show that the North Caucasian Federal District is a permanently arid region. In this regard, we form our hypothesis 1: The level of drought affects the yield in the NCFD.

Since the Russian Federation lacks a sufficient database of statistical data on the dynamics of the level of drought in all regions, for further empirical research, we need to visualize the drought variable as one of the indicators that most characterize this phenomenon. Most often, droughts occur in the summer and are considered the value of temperature deviations from the norm for a particular month (Menzie, 2007). Below is Table 1, where we compared the deals for the yield of grain and leguminous crops in the North Caucasian Federal District with the selected drought indicator, i.e., the temperature deviation in ${ }^{\circ} \mathrm{C}$ from the norm July.

Table 1

The temperature deviations and the yield of grain and leguminous crops

in the North Caucasus Federal District and its regions for 2010-2013

\begin{tabular}{|c|c|c|c|c|c|c|c|c|}
\hline & \multicolumn{2}{|c|}{2010} & \multicolumn{2}{|c|}{2011} & \multicolumn{2}{|c|}{2012} & \multicolumn{2}{|c|}{2013} \\
\hline & $\begin{array}{c}\text { Productivi- } \\
\text { ty (centers } \\
\text { per hectare } \\
\text { of a harves- } \\
\text { ted area) }\end{array}$ & $\begin{array}{l}\text { Tempera- } \\
\text { ture devia- } \\
\text { tion value } \\
\text { ( }{ }^{\circ} \text { C for July) }\end{array}$ & $\begin{array}{l}\text { Productivi- } \\
\text { ty (centers } \\
\text { per hectare } \\
\text { of a harves- } \\
\text { ted area) }\end{array}$ & $\begin{array}{l}\text { Tempera- } \\
\text { ture devia- } \\
\text { tion value } \\
\text { ( }{ }^{\circ} \mathrm{C} \text { for July) }\end{array}$ & $\begin{array}{l}\text { Productivi- } \\
\text { ty (centers } \\
\text { per hectare } \\
\text { of a harves- } \\
\text { ted area) }\end{array}$ & $\begin{array}{l}\text { Tempera- } \\
\text { ture devia- } \\
\text { tion value } \\
\text { (' } \mathrm{C} \text { for July) }\end{array}$ & $\begin{array}{l}\text { Productivi- } \\
\text { ty (centers } \\
\text { per hectare } \\
\text { of a harves- } \\
\text { ted area) }\end{array}$ & $\begin{array}{l}\text { Tempera- } \\
\text { ture devia- } \\
\text { tion value } \\
\text { ( }{ }^{\circ} \text { C for July) }\end{array}$ \\
\hline $\begin{array}{c}\text { North } \\
\text { Caucasian } \\
\text { Federal } \\
\text { District }\end{array}$ & 32,2 & 2,5 & 37,0 & 2,6 & 25,8 & 0,0 & 32,7 & 0,1 \\
\hline $\begin{array}{l}\text { Republic of } \\
\text { Dagestan }\end{array}$ & 22,4 & 2,3 & 22,5 & 3,0 & 20,9 & 0,6 & 23,8 & 0,2 \\
\hline $\begin{array}{l}\text { Republic of } \\
\text { Ingushetia }\end{array}$ & 16,9 & 0,8 & 21,7 & 0,8 & 21,8 & $-2,0$ & 24,4 & $-1,0$ \\
\hline $\begin{array}{c}\text { Kabardino- } \\
\text { Balkar } \\
\text { Republic }\end{array}$ & 37,4 & 3,1 & 40,6 & 3,0 & 42,5 & 0,5 & 52,0 & 0,5 \\
\hline $\begin{array}{l}\text { Karachay- } \\
\text { Cherkess } \\
\text { Republic }\end{array}$ & 27,5 & 3,0 & 30,1 & 2,6 & 30,7 & 0,9 & 43,9 & 0,4 \\
\hline $\begin{array}{c}\text { Republic of } \\
\text { North Osse- } \\
\text { tia - Alania }\end{array}$ & 40,1 & 3,0 & 41,9 & 3,1 & 44,1 & 0,3 & 51,1 & 0,4 \\
\hline $\begin{array}{l}\text { Chechen } \\
\text { Republic }\end{array}$ & 16,7 & 3,0 & 20,5 & 2,7 & 16,0 & $-0,5$ & 17,7 & 0,0 \\
\hline $\begin{array}{l}\text { Stavropol } \\
\text { region }\end{array}$ & 32,6 & 3,0 & 38,3 & 3,1 & 23,5 & 1,0 & 30,8 & 0,4 \\
\hline
\end{tabular}

Source: Federal State Statistics Service. (2018). Regions of Russia. Socio-economic indicators - 2010-2013. (In Russ.) Retrieved December 5, 2020, from https://rosstat.gov.ru/free_doc/doc_2018/region/reg-pok18.pdf

As we can see from the table above, from 2010 to 2013, the North Caucasian Federal District's yield level was unstable with similar results of 32.2 in 2010 
and 32.7 in 2013. However, in 2011, the indicator had a maximum value of 37.0, but the next year it became minimal, amounting to 25.8. Among the regions, we can highlight the Republic of Ingushetia, Kabardino-Balkar Republic, Karachay-Cherkess Republic, and the Republic of North Ossetia - Alania annual stable growth of indicators.

Speaking about the North Caucasian Federal District's temperature deviations, this indicator had maximum values in 2010 and $2011-2.5$ and 2.6, respectively. However, in subsequent years the data was close to zero amounting to 0.0 in 2012 and 0.1 in 2013. In general, the region's situation reflects the entire district's data - the maximum values in 2010-2011 and the minimum in 2012-2013. Only the Republic of Ingushetia had a minimum indicator against other regions' background for the first two years of observation 0.8 and in subsequent years, a significant negative indicator -2.0 in 2012 and -1.0 in 2013.

Comparing both indicators, it becomes clear that temperature deviations do not affect the yield level in our case. However, based on the theoretical background, there is a link between drought and yield. To substantiate obtained data, we note that, according to K. Menzie (2007), sometimes drought does not directly affect output level. If the drought has a local occurrence, then the story of its impact on the region's yield may be insignificant. Moreover, even during intense droughts, there is an intermediate link between drought and yield levels in the form of region vulnerability (see Figure 2). This link is characterized by the resistance of a particular region to the consequences of drought and is a consequence of the human activity. Thus, climate risk in the form of drought is partially controlled by humans. The level of resistance can be expressed in the development of the quality of agriculture (innovative approaches and risk planning) and the use of modern types of grain crops that are least susceptible to droughts (Strashnaya, Maksimenkova, 2011).

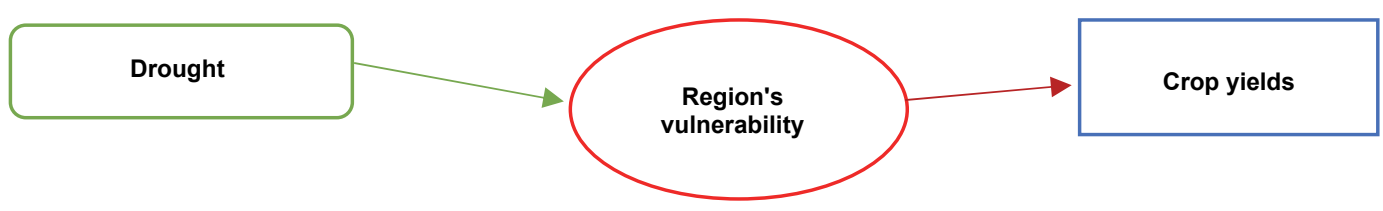

Figure 2. Impact of drought on crop yields

Source: Roberts et al., 2014.

According to data on the level of drought and yield in the North Caucasian Federal District, which on the one hand, indicates a problematic situation with droughts, and on the other hand, the result remains at a reasonably high level; we can conclude that the vulnerability of the region is minimal. In this regard, the climate risk in the form of drought does not pose a severe economic threat to the North Caucasian Federal District. Therefore, hypothesis 1 is not confirmed.

\section{Precipitation and climate migration}

As a rule, heavy precipitation occurs when the mass of air is saturated (i. e., forms clouds) and then rises due to low pressure or mountainous terrain. According to D. Wilks (2011), this process is a cause of a large mesoscale convective cyclone with a minimum diameter of $200 \mathrm{~km}$. 
In general, in Russian Federation, 1976-2016 annual precipitation increased by $2.1 \%$ every ten years (Report on climate risks.., 2017). Speaking about the nature of abnormal precipitation in the North Caucasian Federal District, they are more common in winter. The level of rainfall in the region has an always high level and will only increase.

We have determined that heavy rainfall has an overall destructive effect on any region. Given that it affects many socio-economic infrastructure sectors, the definition of its impact on the economy should form a comprehensive approach. In this context, we believe that heavy precipitation has a devastating effect on the economy and can affect the level of migration by starting climate migration. In this regard, we put hypothesis 2: An increase in precipitation affects the migration decline.

To investigate data on the impact of heavy precipitation on climate migration in the North Caucasian Federal District, it is necessary to mark empirical indicators. As an indicator of heavy rainfall, we select the value of precipitation deviations ( $\%$ to the norm for January). Furthermore, we distinguish the concept of climate migration in the form of interregional migration. Therefore, the lower the indicator, the higher the migration outflow. Below is Table 2, where we compared the value of precipitation deviations and the interregional migration coefficient.

The level of precipitation deviations and interregional migration in the North Caucasus Federal District and its regions for 2010-2013

\begin{tabular}{|c|c|c|c|c|c|c|c|c|}
\hline & \multicolumn{2}{|c|}{2010} & \multicolumn{2}{|c|}{2011} & \multicolumn{2}{|c|}{2012} & \multicolumn{2}{|c|}{2013} \\
\hline & $\begin{array}{c}\text { Inter-regio- } \\
\text { nal migra- } \\
\text { tion rate } \\
\text { (people } \\
\text { per 10,000 } \\
\text { population) }\end{array}$ & $\begin{array}{c}\text { Value of } \\
\text { precipita- } \\
\text { tion devia- } \\
\text { tions (\% to } \\
\text { the norm } \\
\text { for January) }\end{array}$ & $\begin{array}{l}\text { Inter-regio- } \\
\text { nal migra- } \\
\text { tion rate } \\
\text { (people } \\
\text { per } 10,000 \\
\text { population) }\end{array}$ & $\begin{array}{l}\text { Value of } \\
\text { precipita- } \\
\text { tion devia- } \\
\text { tions (\% to } \\
\text { the norm } \\
\text { for January) }\end{array}$ & $\begin{array}{c}\text { Inter-regio- } \\
\text { nal migra- } \\
\text { tion rate } \\
\text { (people } \\
\text { per } 10,000 \\
\text { population) }\end{array}$ & $\begin{array}{l}\text { Value of } \\
\text { precipita- } \\
\text { tion devia- } \\
\text { tions (\% to } \\
\text { the norm } \\
\text { for January) }\end{array}$ & $\begin{array}{l}\text { Inter-regio- } \\
\text { nal migra- } \\
\text { tion rate } \\
\text { (people } \\
\text { per 10,000 } \\
\text { population) }\end{array}$ & $\begin{array}{l}\text { Value of } \\
\text { precipita- } \\
\text { tion devia- } \\
\text { tions (\% to } \\
\text { the norm } \\
\text { for January) }\end{array}$ \\
\hline $\begin{array}{c}\text { North } \\
\text { Caucasian } \\
\text { Federal } \\
\text { District }\end{array}$ & -21 & 205 & -43 & 106 & -51 & 96 & -49 & 60 \\
\hline $\begin{array}{c}\text { Republic } \\
\text { of Da- } \\
\text { gestan }\end{array}$ & -35 & 216 & -75 & 91 & -83 & 109 & -74 & 75 \\
\hline $\begin{array}{c}\text { Republic } \\
\text { of Ingu- } \\
\text { shetia }\end{array}$ & 41 & 200 & 143 & 124 & 88 & 77 & 62 & 96 \\
\hline $\begin{array}{l}\text { Kabar- } \\
\text { dino- } \\
\text { Balkar } \\
\text { Republic }\end{array}$ & -41 & 223 & -71 & 132 & -79 & 82 & -81 & 32 \\
\hline $\begin{array}{l}\text { Karachay- } \\
\text { Cherkess } \\
\text { Republic }\end{array}$ & -53 & 153 & -96 & 100 & -103 & 200 & -93 & 53 \\
\hline $\begin{array}{c}\text { Republic } \\
\text { of North } \\
\text { Ossetia - } \\
\text { Alania }\end{array}$ & -59 & 230 & -105 & 118 & -109 & 122 & -95 & 46 \\
\hline $\begin{array}{l}\text { Chechen } \\
\text { Republic }\end{array}$ & -6 & 206 & -27 & 107 & -37 & 82 & -38 & 60 \\
\hline $\begin{array}{l}\text { Stavropol } \\
\text { region }\end{array}$ & 0 & 153 & -11 & 90 & -13 & 115 & -17 & 53 \\
\hline
\end{tabular}


This data shows that the value of precipitation deviations to the norm for January remained relatively high in all regions. Moreover, a positive indicator means the presence of heavy precipitation. The maximum rate of $230 \%$ is recorded in the Republic of North Ossetia - Alania in 2010. The minimum is $32 \%$ in 2013 in the Kabardino-Balkar Republic. In general, the dynamics of reducing deviations from $205 \%$ in 2010 to $60 \%$ in 2013 is well observed in the North Caucasian Federal District. However, the figure of $60 \%$ still indicates a high level of precipitation.

Speaking about the interregional migration coefficient, it has a negative value for 2010-2013 both in the North Caucasian Federal District ( -21 in 2010; -43 in $2011 ;-51$ in $2012 ;-49$ in 2013 ), and separately for all regions except for the Republic of Ingushetia, where the indicators are positive and even have growth dynamics from 41 in 2010 to 62 in 2013. Among all areas, the maximum decline is recorded in the Republic of North Ossetia - Alania with an indicator of -109 for 2012.

Comparing both indicators in dynamics, it is clear that there is no clear correlation between them. For example, from 2010 to 2013, the interregional migration coefficient decreased, and the value of precipitation deviations in the North Caucasian Federal District. Nevertheless, based on the theoretical and methodological background, we can assume that despite the lack of a direct correlation in dynamics, heavy precipitation in the North Caucasian Federal District can still be a reason for climate migration. This is possible because migration in the examined period had strong negative indicators with a minimum of -21 in 2010 . The amount of precipitation was consistently high, with a minimum excess of $60 \%$ in 2013 . Thus, we can consider that due to the consistently high level of rainfall, the level of migration growth remains consistently low. Therefore, hypothesis 2 is partially confirmed.

\section{Conclusion}

Problems associated with climate change are going to increase each year. The reason for this is the ongoing changes in the global socio-economic system (Lukyanets et al., 2020). The next two decades will become crucial for testing existing climate models and theories. Due to the current rate of increase in average global temperatures, new research and working hypotheses are designed to minimize future risks.

Today we live on a warmer planet than we did three decades ago. It should be noted that the increase in heat leads to a change in the planetary energy balance and creates the need for more accelerated and deep processes of energy restructuring - through atmospheric circulation and the movement of air masses. These processes cause concern and force us to prepare for the occurrence of more frequent extreme atmospheric events. We must be aware that climate risks will play an essential role in the foreseeable future.

In this paper, we have determined that Russian Federation is exposed to many climate risks. Moreover, it remains unclear to what extent do these risks influence the socio-economic position of the regions. On the North Caucasian Federal District example, we have determined that some climate risks may have 
a permanent manifestation. However, their effect is not always dangerous for the economy. This is possible due to the adaptation of those sectors of the economy that are at risk. In our case, despite the severe level of drought, the yield of grain and leguminous crops in the North Caucasian Federal District and its subjects remained at a high level. Thus, it can be concluded that the agricultural sector of the North Caucasian Federal District is well prepared for droughts and can minimize their effects.

However, adaptation to a particular climate risk does not mean that the region can fully minimalize future economic losses. With a slight decrease in the number of unintended dangerous hydrometeorological phenomena, including hydrological and agrometeorological, which caused significant damage to the economy's sectors and the life of the population, their total annual number in the last decade remains consistently high (Report on climate risks.., 2017). In other words, climate risks are a complex structure with an increasing impact factor. A comparative analysis of precipitation and migration levels in the North Caucasian Federal District shows a slight change in climate migration. We assume that it will become more significant over time. Thus, one climate risk can cause another, and their effect will only increase. Some economic sectors can be protected from certain climate risks, but it is impossible to save them all. We believe that only a comprehensive approach designed to reduce industry and people's impact on climate change will become a solution to the ongoing climate risks.

\section{References}

Balzter, H., Gerard, B., Weedon, G., Grey, W., Combal, B., Bartholome, E., Bartalev, S.A., \& Los, S. (2007). Coupling of vegetation growing season anomalies with hemispheric and regional scale climate patterns in Central and East Siberia. Journal of Climate, 20(15), 3713-3729.

Bereza, O.V., Loupian, E.A., \& Strashnaya, A.I. (2015). On the possibility to predict the yield of winter wheat in the Middle Volga region. The Basis of Integration of Land and Satellite Data, 12(1), 20-35. (In Russ.)

Harmeling, S., Chamling, S., Singh, T., \& Anderson, T. (2015). Loss and damage: Climate reality in the 21 st century. ActionAid.

Hewitt, K. (1997). Regions at risk. A geographical introduction to disasters. London, Longman.

Lukyanets, A., Ryazantsev, S., Moiseeva, E., \& Manshin, R. (2020). The economic and social consequences of environmental migration in the central Asian countries. Central Asia and the Caucasus, 21(2), 142-156. http://dx.doi.org/10.37178/ca-c.20.2.13

McLeman, R. (2013). Climate and human migration: Past experiences, future challenges. Cambridge, Cambridge University Press.

Menzie, K. (2007). Methods of evaluating agrometeorological risks and uncertainties for estimating global agricultural supply and demand. Managing weather and climate risks in agricultural. Berlin, Heidelberg; New York, Springer.

Mishra, A., \& Singh, V. (2010). A review of drought concepts. Journal of Hydrology, 391, 202-216.

Pavlova, V.N., \& Varcheva, S.E. (2016). Analysis and assessment of vulnerability and risk of production of crops under climate change in the Kaluga region. Proceedings of the Regional Competition of Fundamental Research Projects, (21), 246-251. (In Russ.)

Pelling, M. (2011). Adaptation to climate change: From resilience to transformation. London, New York, Routledge.

Report on climate risks in the Russian Federation. (2017). Saint Petersburg. (In Russ.) 
Roberts, E., Van der Geest, K., Warner, K., \& Andrei, S. (2014). Loss and damage: When adaptation is not enough. Environmental Development, 11, 219-227.

Rusin, I.N. (2003). Natural disasters and outlooks for their forecasting. Saint Petersburg, RSHU Publ. (In Russ.)

Shkolnik, I., Pavlova, T., Efimov, S., \& Zhyravlev, S. (2017). Future changes in peak river flows across northern Eurasia as inferred from an ensemble of regional climate projections under the IPCC RCP8.5 scenario. Climate Dynamics, 50, 215-230. http://dx.doi.org/10.1007/s00382-017-3600-6

Strashnaya, A.I., Maksimenkova, T.A., \& Chub, O.V. (2011). Agrometeorological features of the 2010 drought in Russia in comparison with droughts of previous years. Proceedings of the GMC of Russia, 345, 194-214. (In Russ.)

Wilks, D. (2011). Statistical methods in the atmospheric sciences. 3rd ed. Oxford; Waltham, MA, Academic Press.

\section{Сведения об авторах / Bio notes}

Лукьянеи Артем Сергеевич, кандидат экономических наук, ведущий научный сотрудник, Институт демографических исследований, Федеральный научно-исследовательский социологический центр РАН. AuthorID: 605126. E-mail: artem_ispr@mail.ru

Брагин Алексей Дмитриевич, аспирант, младший научный сотрудник, Институт демографических исследований, Федеральный научно-исследовательский социологический центр PAH. Author ID: 1092482. E-mail: alexbragin562@gmail.com
Artem S. Lukyanets, Ph.D. (Econ.), leading researcher, Institute for Demographic Research FCTAS RAS. AuthorID: 605126. E-mail: artem_ispr@mail.ru

Alexey D. Bragin, M.Sc. (Political Science), junior researcher, Institute for Demographic Research FCTAS RAS. Author ID: 1092482. E-mail: alexbragin562@gmail.com 